\title{
Performance of Broiler Chicken Carcass Provided with Water Extract (Phyllanthus niruri L) and Moringa (Moringa oleifera Lam)
}

\author{
Puji Astuti ${ }^{1}$ and Heru Suripta ${ }^{1}$ \\ ${ }^{1}$ Akademi Peternakan Karanganyar \\ Coresponding author : tutiamir88@gmail.com
}

This study aims to determine the performance of broiler carcasses given meniran and moringa extracts. The research was conducted for 28 days at the Animal Husbandry Practice Unit (UPT) of the Karanganyar Animal Husbandry Academy. The material used was 60 broiler strain Ross strains aged 4 days, kept in 12 experimental units, each unit consisting of 5 chickens with an average initial weight of $95.77 \pm 4.79 \mathrm{~g}$. The first treatment (T0) control, chicken without giving meniran and moringa extracts, the second treatment (T1) the chicken was given $5 \mathrm{ml}$ meniran extract per liter of drinking water, the third treatment (T2) the chickens were given $2.5 \mathrm{ml}$ meniran extract and moringa 2 extract, 5 Moringa extracts per liter of drinking water, the fourth treatment (T3) of chickens was given Moringa extract $5 \mathrm{ml}$ per liter of drinking water. The variables observed included drinking water consumption, final body weight, carcass weight, carcass percentage, and abdominal fat percentage. The design used was a completely randomized design (CRD). The data were analyzed for variety and if there was a significant effect of the treatment, it was continued with the Duncan Multiple Distance Test to determine differences in treatment. The results showed that drinking water consumption, percentage, and percentage of abdominal fat were not significantly different between treatments, final body weight (g / head / day)., and carcass weight was significantly different between treatments. The conclusion of this research is that giving meniran and moringa extracts in drinking water does not affect the performance of broiler chicken carcasses.

Keywords : Moringa meniran extract, final body weight, carcass weight, carcass percentage, abdominal fat percentage

\section{Introduction}

Chicken meat is one of the livestock products that plays an important role in meeting the nutritional needs of the community and currently consumers are increasingly selective in choosing livestock products with good carcass quality. Selective selection by consumers requires breeders to produce chicken meat with low carcass fat content. Excess fat in chickens is indicated by the amount of abdominal fat that is built up in the body. The quality of carcass is influenced by several factors, including the ration consumed by broiler chickens. Carcass weight and percentage are influenced by many factors including chicken weight, body fat, breast meat, gender nutrition factors and slaughter age. The percentage of carcass is often used to assess the production of meat livestock (Priyatno, 2003).

Broiler chicken rations generally consist of vegetable and animal ingredients which contain a lot of high energy which is used to meet livestock needs for food substances, both for basic living and for optimum growth, but tends to lead to fat 
accumulation in broilers. One of the efforts that can be done is by giving supplementary feed and giving antibiotics, one of which is phytobiotics (from herbal plants).

Meniran (Phillanthus niruri L) contains several chemical components including flavonoids which can stimulate the immune system of livestock to work better. Meniran also contains lignins, alkaloids, triterpenoids, fatty acids, vitamin $\mathrm{C}$, potassium, resin, tannins, and geranins. The essential fatty acids (richnoleic acid, linoleic acid and linolenic acid) reduce cholesterol content. The leaves of Moringa (Moringa oleifera Lam) are traditional medicinal plants which have high nutrition, are antibacterial, and contain beta carotene as an active carcass color. The phytochemical compounds contained in it are: flavonoids, saponins, tannins, and several other phenolic compounds that have antimicrobial activity (Bukar et al., 2010). Flavonoids as antioxidants and maintain the body's immune system are able to reduce blood cholesterol levels and increase HDL levels, while saponins have been shown to have anticancer, antimicrobial properties that can increase immunity so that they are resistant to disease and reduce blood cholesterol levels. Tannin has antiseptic properties so that it has a good effect on the digestive tract. Other ingredients consist of catechols, steroids, triterpenoids, anthraquinones, alkaloids, and sugar. (Santoso., 2002).

Healthy livestock, immune to diseases with a good immune system, will increase their feed consumption, so they are expected to be able to produce better carcasses.

\section{Materials and Methods}

The study used 60 broilers, reared in 12 treatment units, each consisting of 5 chickens. The research location is in the Animal Practice Unit (UPT) of the Karanganyar Animal Husbandry Academy (APEKA). The materials used were extracts of meniran and moringa, and broiler feed with a protein content of $22 \%$.

The treatment applied was the administration of 1 meniran and moringa extracts as much as $5 \mathrm{ml} /$ liter of drinking water as follows:

1. Control (T0): chicken without extract administration

2. Treatment 2 (T1): chickens were given $5 \mathrm{ml}$ of meniran extract / liter of drinking water

3. Treatment 3 (T2): chicken was given $2.5 \mathrm{ml}$ meniran extract and $2.5 \mathrm{ml}$ moringa extract per liter of drinking water

4. Treatment 4 (T3): chickens were given Moringa extract as much as $5 \mathrm{ml} /$ liter of drinking water

Extract Making

Meniran and moringa are dried to dry. After drying, the meniran and moringa are ground into a fine powder. The fine powder obtained was then extracted by dissolving the powder in water at 900C (ratio 1:10) for 20 minutes while stirring to make it homogeneous. After chilling then filtered. The extract obtained is then evaporated until a thick extract is obtained.

The parameters measured include drinking water consumption, final body weight, carcass percentage, carcass weight and abdominal fat percentage. The data obtained were analyzed for variance using a completely randomized design. The Duncan multiple region test was used to determine the differences between treatments. 


\section{Results and Discussion}

Based on the results of the study, there was no difference in drinking water consumption, carcass percentage and abdominal fat percentage between the control treatment and administration of meniran and moringa extracts $(\mathrm{P}>0.05)$, while the final body weight and carcass weight were influenced by the administration of the extract $(\mathrm{P}$ $<0.05$ ). Carcass performance data can be seen in Table 1 .

Table 1. Performance of Broiler Chicken

\begin{tabular}{lrrrr}
\hline \hline \multirow{2}{*}{\multicolumn{1}{c}{ Parameter }} & \multicolumn{4}{c}{ Perlakuan } \\
\cline { 2 - 5 } & \multicolumn{1}{c}{ T0 } & \multicolumn{1}{c}{ T1 } & \multicolumn{1}{c}{ T2 } & \multicolumn{1}{c}{ T3 } \\
\hline Water consumption $(\mathrm{ml} / \mathrm{h} / \mathrm{d})$ & 209.07 & 190.19 & 191.76 & 197.05 \\
Final body weight $(\mathrm{g} / \mathrm{h}$ head) & $1836.5^{\mathrm{a}}$ & $1833.1^{\mathrm{a}}$ & $1838.8^{\mathrm{a}}$ & $1881.7^{\mathrm{b}}$ \\
Carcass weight $(\mathrm{g} / \mathrm{head})$ & $1274.67^{\mathrm{a}}$ & $1301.10^{\mathrm{a}}$ & $1312.43^{\mathrm{a}}$ & $1373.57^{\mathrm{b}}$ \\
Percentage of carcass $(\%)$ & 69.43 & 70.98 & 71.37 & 72.98 \\
Percentage of abdominal fat $(\%)$ & 0.95 & 0.89 & 0.95 & 0.78 \\
\hline
\end{tabular}

Description : different superscripts on the same line indicate significant differences $(\mathrm{P}<0.05)$

\section{Water Consumption}

Consumption of drinking water is something that is needed by the body of livestock. Because most of the composition of the livestock body is supported by water. Water fills the livestock body up to $60-70 \%$. This is in accordance with the opinion of Bishop (2011) that chickens consume drinking water about 1.6-2 times of feed consumption. Tillman et al., (2008) added that water is the most important element as a heat transfer which helps the digestive process and serves as a medium for transportation of metabolic products and metabolic waste products. Table 1 shows that drinking water consumption is not significantly different $(\mathrm{P}>0.05)$, this means that the administration of meniran and moringa extracts in drinking water does not affect the drinking water consumption of broiler chickens. The level of livestock drinking water consumption is influenced by several factors such as the condition of the livestock, body weight, and several other factors such as environmental temperature and livestock health. In this study, the ambient temperature (average 300C), health and nutritional content of the feed were the same so that drinking water consumption was the same. According to Nuriyasa (2017) chicken is less sensitive to taste, because it only has 24 taste senses, so drinking water consumption is not affected by the administration of meniran or moringa extracts.

\section{Final Body Weight}

The results showed that giving the extract to the final body weight was significantly different $(\mathrm{P}>0.05)$. The final body weight of moringa extract treatment was significantly different from other treatments. This means that the provision of 
moringa extract can affect the final body weight of broiler chickens. Dun Moringa contains phytochemical compounds, namely flavonoids, saponins, tannins, and several other phenolic compounds that have antimicrobial activity (Bukar et al., 2010). Saponins function as antimicrobials that can increase immunity so that they are resistant to disease and smooth the digestive system. The tannin content in moringa has antiseptic properties so that it has a good effect on the digestive tract (Dewi et al, 2014). A good digestive system causes food to be digested easily and results in better body weight. The presence of antimicrobials in saponins can kill harmful microbes in the digestive tract, so that beneficial microbes can increase. Thus the chances of absorption of nutrients can be more optimal so that it has an impact on increasing the growth of chickens.

\section{Carcass Weight}

The administration of meniran and moringa extracts affected $(\mathrm{P}<0.05)$ carcass weight. It is possible that the saponin and tannin content in moringa affects the performance of digestive enzymes, so that the carcass weight is higher than the administration of meniran extract or a mixture of meniran and moringa. According to AAK (2003), the level of digestibility can affect growth. High and low live weight in line with carcass weight level, the higher live weight is in line with high carcass weight and the lower live weight is in line with low carcass weight so that the resulting ratio of meat and bone is getting smaller. Carcass weight is the cut weight without head, legs, offal and fur. The carcass weight standard for Ross strain broiler chickens maintained for 35 days is about 1,521 $\mathrm{g}$ (Aviagen, 2007).

\section{Percentage of Carcass}

The results of the analysis on the percentage of broiler carcasses showed that the application of meniran and moringa extracts in drinking water gave no significant difference (Sig. 240). This means that giving meniran and moringa extracts in drinking water has no effect on the percentage of carcass. According to Mahfudz (2009), the percentage of carcass affects the size of the live weight. The factors that influence it can be from the ration, the environment and the livestock itself. According to Qotimah et al. (2014) the percentage of carcass can be influenced by the level of ration consumption which results in a small ratio of bone meat.

The percentage of carcass in this study ranged from $69.43 \%-72.98 \%$. This result is consistent with the research of Salam et al., (2013), namely the percentage of broiler carcasses fed with black cumin flour in rations ranged from 64.69 to $71.66 \%$. This value is also in accordance with the normal limit of carcass percentage, where the normal carcass percentage for broilers ranges from 65 - 75\% of body weight (Daud et al., 2007). The main factors affecting the percentage of carcasses are age, sex and strain. Other factors are genetics, feed and management (Seeman, 1981). According to Wahju (2004), the percentage of carcass is influenced by live weight and carcass weight. High carcass weight will result in a high percentage of carcass. Factors that influence the percentage of carcass are gender, live weight, feed quality and non-carcass weight. According to Tilman et al. (1998) stated that the percentage of carcass is influenced by 
cutting weight, carcass weight and abdominal fat weight. High carcass percentage due to high thigh and breast meat weight and low abdominal fat weight can increase carcass percentage.

\section{Percentage of Abdominal Fat}

There was no difference between meniran and moringa extracts in drinking water on the percentage of abdominal fat. This means that the administration of meniran and moringa extracts in drinking water has no effect on the percentage of abdominal fat. As is well known, abdominal fat is a by-product of livestock which can affect carcass quality. Therefore, the lower the percentage of abdominal fat, the better the carcass is obtained. This is in accordance with Yusniastuti (2012) that the high and low quality of broiler carcass is determined by the amount of abdominal fat available from the broiler. The percentage of broiler chicken carcass abdominal fat ranged from $0.73 \%$ to $3.78 \%$ (Becker et al., 1979). The low percentage of abdominal fat produced in this study $(0.78$ $-0.95 \%$ ) indicates that the resulting fatty condition tends to be better. Abdominal fat has a correlation with total carcass fat, the higher the abdominal fat content, the higher the carcass fat content in broilers (Salam et al., 2013). This amount varies depending on genetic factors, feed, sex, age, and environment. Utilization of the benefits of Moringa leaves can be an alternative to reduce fat content and replace antibiotics, because of the rich and varied content of phytochemical compounds, as well as efficacious as antibacterial agents and can increase immunity (Yuniza and Yuherman, 2015). This amount varies depending on genetic factors, feed, sex, age, and environment.

\section{Conclusion}

Based on the research results it can be concluded that :

1. Meniran and moringa extracts did not affect drinking water consumption, carcass percentage and abdominal fat percentage.

2. The provision of Moringa extract can increase the final body weight and carcass weight of broiler chickens.

\section{References}

Aviagen. 2007. Strain Ross (Broiler Performance Objectives). http://www.aviagen.com. Retrieved 10 June 2020.

Kanisius Agricultural Action (AAK). 2003. Breeding Broilers. 18th mold. Canisius. Jakarta

Becker W. A, J.V. Spencer, L.W. Minishand and J.A. Werstate. 1979. Abdominal and carcas fat in five broiler strain. Poult. Sci. 60: 692-697.

Bishop, 2011. How is the Quality of Our Farm Broiler Drinking Water. http://www.ceva.co.id. 
Bukar, A., T. I. Uba and Oyeyi. 2010. Antimicrobical Profile of Moringa oleifera Lam. Extracts Against Some Food-Borne Microorganisms. Bayero Journal of Pure and Applied Sciences, 3 (1): 43-48.aud

Daud, M., W. G. Piliang and P. Kompiang. 2007. Percentage and quality of broiler carcasses fed with probiotics and prebiotics in the ration. JITV, 12 (3): 167-174

Dewi, Trisna K., I. G. N. G, Biduradan D. P. M. A. Candrawati. 2014. The Effect of Giving Moringa oleifera (Moringa oleifera) and Garlic (Allium sativum) Leaf Extract through Drinking Water on the appearance of broilers aged 2-6 weeks. E Journal of Animal Husbandry and Tropical. Faculty of Animal Husbandry, Udayana University.

Mahfudz. 2009. Carcass and Abdominal Fat of Broilers Given Beer Waste in Rations. Proceedings of the National Seminar on Animal Husbandry Awakening. Animal Husbandry Research and Development Center. Bogor.

Nuriyasa, I M., 2017. Environment and Livestock Productivity. Lecture dictates. Animal Husbandry Study Program. Faculty of Animal Husbandry. Udayana University. Denpasar

Pratikno, H. 2011. Broiler Chicken Abdominal Fat (Gallus sp). BIOMA Journal. Vol. 13. No. 1.

Priyatno, M. A. 2003. Established a Chicken Slaughtering Business. Self-help spreader. Jakarta.

Qotimah, S., U. Santoso, and E. Soetrisno. 2014. Effect of protein levels and katu leaf extract supplementation (Sauropus androgynus) on the quality of broiler carcass. JSPI. 9 (2)

Regards, S., A. Fatahillah, D. Sunarti and Isroli. 2013. Carcass Weight and Abdominal Fat of Broiler Chickens Given Black Cumin Flour in Summer Rations. Animal Science 11 (2): 84 - 89.

Santoso, U. 2002. The usefulness of Sauropus androgynus as feed supplement in broiler chickens. Poultry International (in press).

Seeman, G., 1981. The Influence of Age, Sex and Strain on Yield and Cutting of Broiler Quality of Poultry Meat. Spelderholf Institute for Poultry Research Beekbergen.

Sjofjan, O. 2008. Effects of Using Moringa oleifera (Moringa oleifera) Leaf Flour in Feed on Performance of Broiler Production. Faculty of Animal Husbandry, Universitas Brawijaya. Faculty of Animal Husbandry. Brawijaya University. Poor.

Tillman, A. D., R. Soedomo, P. Soeharto and I. Soekamto. 1998. Basic Forage Science. Gadjah Mada University Press, Yogyakarta.

Revelation. 2004. Unconventional Poultry Feed Materials. Faculty of Animal Husbandry-Fisheries, University of Muhammadiyah Malang.

Yuniastuti, A., 2002. The effect of fibrous feed on chicken rations on fat and cholesterol levels of broiler meat. JITV, 9 (3): 175 - 183. 
Yuniza, A. and Yuherman. 2015. Content of Phytochemical Compound and Antibacterial Activity of Cinnamon Leaf (Cinnamomum burmanii) and Noni Fruit and Leaf (Morinda citrifolia L) Mixture Extract to Replace Antibiotics. Pakistan Journal of Nutrition 14 (8): 492-497. 